\title{
Lisansüstü Eğitimde Yapı ve Süreç: Araştırma Üniversitelerinde Örgüt İklimi ve Lisansüstü Deneyimler
}

\section{Structure and Process of Graduate Education: Organizational Climate and Graduate Experiences in Research Universities}

\author{
Hasan Yücel ERTEM*
}

\begin{abstract}
Öz: Lisansüstü eğitim akademik, ekonomik, politik ve sosyolojik katkılar sunan önemli bir yükseköğretim düzeyidir. Bu çalı̧̧ma lisansüstü eğitim alan öğrencilerin örgüt iklimi algıları ile ilişkili faktörleri ve onların lisansüstü deneyimlerini inceleyerek lisansüstü eğitimin yapı ve süreçlerini ortaya çıkarmayı amaçlamaktadır. Çalışmada karma yöntem deseni kullanılmıştır. Çalışmanın nicel boyutu nedensel karşılaştırma, nitel boyutu ise olgu-bilim deseni üzerine kuruludur. Nicel kısımda örgüt iklimi ile ilişkili faktörler test edilmişken nitel kısımda ise lisansüstü öğrencilerin deneyimleri irdelenmiştir. Nicel kısımda bağımlı değişken örgüt iklimi algısı, bağımsız değişkenler ise cinsiyet, medeni durum, yaş, akademik alan, program düzeyi ve dönemdir. Nitel kısımda ise temalar akademik, sosyal, kültürel ve yönetimsel alanlardaki deneyimlerle ilgilidir. Çalı̧̧manın evreni araştırma üniversitelerindeki lisansüstü öğrenciler olup örneklem ise bu evrenden seçilen lisansüstü öğrencidir. Nicel veri 442 öğrenciden toplanırken nitel veri ise aynı örneklem içinde yer alan sekiz öğrenciden toplanmıştır. Çalışmada lisansüstü eğitimde örgüt iklimi ölçeği, yarı-yapılandırılmış görüşme formu ve dokümanlar veri toplama araçları olarak kullanılmıştır. Nicel veriler tek ve çift yönlü varyans analizi ile incelenirken nitel veri ise içerik analizine tabi tutulmuştur. Akademik alan, medeni durum, yaş ve program düzeyinin örgüt iklimi algılarında anlamlı farkl1lık oluşturduğu tespit edilmiştir. Akademik deneyimler ile sosyoekonomik deneyimlerin kültürel deneyimler ile yönetimsel deneyimlere göre nispeten daha olumlu olduğu görülmüştür. Lisansüstü eğitimde yapı ve süreç değişkenlerinin girdi, süreç, çıktı ve geribildirim öğeleri ile açıklanabildiği ortaya çıkmıştır. Lisansüstü eğitimin bütüncül bir bakış açısıyla değerlendirilmesi önerilmektedir.
\end{abstract}

Anahtar Kelimeler: Lisansüstü eğitim, yükseköğretim, araştırma üniversitesi, örgüt iklimi

\begin{abstract}
Graduate education is a kind of higher education level offering academic, economic, political, and sociological contributions. The aim of the current study is to reveal structure and process in graduate education by investigating factors related to organizational climate perceptions of graduate students and their graduate experiences. The design of the current study was mixed-method in which quantitative method is based on causal-comparative design while qualitative method is based on phenomenological design. Quantitative part checked variables related to organizational climate while qualitative part focused on experiences of graduate students. For the quantitative part, dependent variable was organizational climate whereas independent variables were gender, marital status, age, academic program level, and semester. For quantitative part, initial themes were related to academic, social, cultural, and administrative experiences. The population of the study will be graduate students in research universities from which graduate students were chosen as sample. Quantitative data were collected from 442 graduate students while qualitative data were collected from eight students in the same sample. Data collection tools of the current study were scale of organizational climate in graduate education, semi-structured interview, and documents. Quantitative data were analysed via one-way and two-may ANOVA while qualitative data were run with content analysis. Academic field, marital status, age, and program level mad significant differences on perceptions of organizational climate. The study showed that academic and socioeconomic experiences were more positive than cultural and administrative experiences. Process and structure in graduate education may be fitted on input, process, output, and feedback mechanism. A holistic perspective to evaluate graduate education is recommended.
\end{abstract}

Keywords: Graduate education, higher education, research university, organizational climate

\footnotetext{
* Dr. Araş. Gör., Zonguldak Bülent Ecevit Üniversitesi, Ereğli Eğitim Fakültesi, Zonguldak-Türkiye, ORCID: 0000-
} 0001-9058-641X ,e-posta: ertem@beun.edu.tr 


\section{Giriş}

Lisansüstü eğitim sadece yükseköğretimin bir düzeyi olmakla kalmaz, yükseköğretimdeki birçok dinamiğe direkt etkilerde bulunarak yükseköğretimin anlam kazanmasına katkı sağlar. Üniversite bünyesinde geliştirilen araştırma \& geliştirme faaliyetlerinin ciddi bir kısmı lisansüstü eğitim ile yetişen insan kaynağı aracılığıyla gerçekleştirilmektedir. Dolayısıyla lisansüstü eğitim önemli ekonomik katkılar sunmaktadır. Lisansüstü eğitim akademik anlamda da lisans eğitimini beslemektedir. Üniversitelerin öğretim işlevi için oluşturulan öğretim programlarının güncellenmesi ve değiştirilmesi süreçlerinde lisansüstü eğitim bileşenlerinin ihtiyaç analizleri öğretim programlarını şekillendirmektedir. Politik anlamda da lisansüstü eğitimin katkıları yadsınamaz. Yükseköğretimin ihtiyaç duyacağı nitelikli akademisyen yetiştirme politikalarında lisansüstü eğitime özel bir rol verilmiştir. Örneğin, YÖK tarafından düzenlenen Öğretim Üyesi Yetiştirme Programı veya üniversitelerin 35. Madde görevlendirmeleri lisansüstü eğitim üzerinden yürütülmektedir. Farklı meslek dallarında görev yapan bireylerin mesleki gelişimleri için de lisansüstü eğitime dâhil oldukları açıktır. Özetle, lisansüstü eğitim ekonomik, akademik, politik ve sosyolojik amaçlara hizmet eden önemli bir yapı ve süreçtir.

Türkiye yükseköğretiminde son yıllarda lisansüstü eğitimle ilgili önemli atılımlar dikkat çekmektedir. Üniversitelerin araştırma ve bölgesel kalkınma odaklı gibi sınıflamalarla desteklenmesi, tematik alanlardaki doktora öğrencilerinin desteklenmesi, doktora öğrencilerinin yurtdışına gönderilmesi ve doktoralı araştırmacı istihdamı bunlara örnek olarak gösterilebilir. Tüm bu gelişmelerin yükseköğretim kurumlarını olumlu etkilemesi hiç kuşkusuz ki bu kurumlarda solunan hava ile yakından ilişkilidir. Başka bir deyişle, yükseköğretimde yapılmak istenen reformların etkili ve kalıcı olması yükseköğretim kurumlarının örgüt iklimine de bağlıdır. Örgüt iklimi, akademik gelişimden sosyal ilişkilere kadar lisansüstü eğitimle ilgili birçok yapı ve süreci barındırmaktadır.

\section{Yükseköğretim}

Yükseköğretim insanları sosyal, akademik ve duygusal olarak geliştirmekle kalmaz; toplumların kalkınmasına ve ülkelerin gelişmesine de katkı sağlar. Yükseköğretim bireylerin daha geniş ekonomik kazanımlar ve kariyer alternatifleri edinmesini sağlamaktadır (Ishitani, 2006). OECD (2017) raporuna göre bireyin yükseköğretim mezunu olması onun işgücüne katılımını \%85 artırmaktadır. Toplumsal kalkınma açısından bakılacak olursa; Gölpek (2011) yükseköğretimin çocuk bakımı ve ilgisine, suç oranlarındaki düşüşe ve kadınların eğitimi ile istihdamı üzerine olumlu etkileri olduğunu vurgulamaktadır. Benzer şekilde OECD (2015) raporu yükseköğretimin yaşam doyumu, yaşam beklentisi ve oy verme gibi üç önemli sosyal kazanımından bahsetmektedir. Yükseköğretim ülkelerin ekonomik kalkınmaları için de söz sahibidir. OECD (2017) raporu yükseköğretim mezun oranlarının fazla olduğu ülkelerde milli gelirin ve işgücüne katılımın fazla olduğunu göstermektedir. Diğer taraftan, yükseköğretimin bu katkıları sunmasında araştırma ve geliştirme faaliyetlerine dayalı bilimsel çalışmaların büyük önemi vardır. Araştırma kültürü, teknolojik ilerleme ve girişimcilik gibi önemli bilimsel süreçler yükseköğretimin misyonlarıdır (Özer, 2011; Öztemel, 2013; Şen, 2012). Sonuç olarak, yükseköğretim bilimin üretilmesi ve yayılması yoluyla bireye, topluma ve ülkeye önemli kazanımlar sağlamaktadır.

Yükseköğretimin yönetimi ve yönetişimi yükseköğretimin işlevi ve katkıları açısından büyük önem arz etmektedir. Geçmişten bugüne Türkiye yükseköğretiminde darbelerin ve kimi sancilı dönemlerin izleri görünse de son y1llarda uygulamaya konan reform ve politikalar yükseköğretimde bazı alanlarda iyileşmeler göstermiş̧tir. Araştırmacılar tarafından eleştirilen aşırı merkeziyetçi yapı (Çelik ve Gür, 2014) Yükseköğretim Kurulu Başkanlığı'nın yaptığı yetki devirleriyle yumuşatılmıştır. Diğer taraftan, yükseköğretim kurumlarının finansal problemleri alan yazın tarafından sıkça dile getirilmektedir. Örneğin, Hauptman (2007) yükseköğretimdeki ekonomik durumları 3 farklı pencereden yorumlamıştır. Politika belirleyicilerinin penceresinden bakıldığında sağlık, güvenlik ve ulaşım gibi kalemlerle yükseköğretim arasında bir seçme ve dengeleme mekanizması dikkat çekmektedir. Üniversite penceresinden bakıldığında yetersiz olan kaynakların eğitime ya da araştırmaya dağılımı konusunda endişeler göze çarpmaktadır. Öğrenciler ve ailelerinin penceresinden bakıldığında ise yükseköğretime ne kadar para ayrılması 
gerektiği sorusu gündeme gelmektedir. Özerklik (Estermann, Nokkala ve Steinel, 2011), hesap verebilirlik (El-Khawas, 2007), kültür (Bergquist ve Pawlak, 2008) ve stratejik planlama (Bess ve Dee, 2008) yükseköğretimde sıkça vurgulanan süreçlerin başında gelmektedir.

\section{Lisansüstü eğitim}

Türkiye'de lisansüstü eğitim yapısal olarak altı türden meydana gelmekte olup bunlar Tezsiz Yüksek Lisans, Tezli Yüksek Lisans, Bütünleşik Doktora, Doktora, Sanatta Yeterlik ve Tipta Uzmanlık programlarıdır. Lisansüstü eğitimin işleyişi enstitüler üzerinden sağlanmakta olup disipliner ve disiplinlerarası programlar aracılı̆̆ıyla öğretim ve araştırma faaliyetleri yürütülmektedir. Lisansüstü programlara kayıt olabilmek için niyet mektubu, referans, lisans not ortalaması, yazılı veya sözlü alan sınavı, yabancı dil puanı ve Akademik Personel ve Lisansüstü Eğitim Sınavı (ALES) gibi ölçütlerin karşılanması beklenebilir. Lisansüstü eğitime kabul edilen ve kayıt olan öğrencilerin belirli süreçleri tamamlaması ve derece alması beklenir. Lisansüstü eğitime dair yönetmelikler üniversiteden üniversiteye değişse de belirli sayıda dersin tamamlanması, tez önerisinin savunulması ve tezin savunulmas1 Yüksek Lisans eğitiminde; ders yükünün tamamlanması, Doktora Yeterlik Sınavı'nda başarılı olma, tez önerisinin savunulması, tez süreçlerinin raporlanması ve tezin savunulması ise Doktora eğitiminde derece almak için başarı ile tamamlanması gereken süreçlerdir. Her bir süreç ve genel eğitim süreçleri için azami süreler bulunmaktadır. Örneğin, doktorada derslerin tamamlanıp Doktora Yeterlik Sınavı'na girebilmek için asgari 5 dönem hak verilmiş, Doktora eğitimi içinse bir öğrencinin azami süre olarak 12 dönem hakkı vardır. Yüksek Lisans derecesi alanlar Uzman, Doktora derecesi alanlar ise Doktor unvanı almaya hak kazanmaktadır.

Türkiye'de lisansüstü eğitim ile ilgili konuları çalışan araştırmalar bulunmaktadır. Bu çalışmaların çoğu lisansüstü eğitimdeki problemleri ele almaktadır. Karakul-Kayahan ve Karakütük (2014) yaptığı çalışmada akademisyenlerin lisansüstü eğitime başvuruda ele alınan not ortalaması ve yabancı dil puanının ALES'e oranla daha önemli gördüklerini bulmuştur. Alabaş, Kamer ve Polat'ın (2012) çalışması akademisyen olma isteği, kişisel gelişim ve meslekte yükselme gibi faktörlerin lisansüstü eğitim alma sebepleri olduğunu ortaya koymuştur. Ölçer ve Koçer (2015) yükseköğretimde iletişim süreçlerini araştırmış ve çalışmaları resmi ve güvensiz iletişimin baskın olduğunu göstermiştir. Ersöz, Kabak ve Yılmaz (2011) lisansüstü eğitimde ders seçimi ile ilgili bir çalışma yürütmüş ve dersin içeriği, ders süresi, dersi veren öğretim elemanı, dersin yeterliği ve kuram-uygulama birlikteliği gibi faktörlerin ders seçiminde etkili olduğunu bulmuştur.

Lisansüstü eğitimde sosyal güvence problemi (Karaman ve Bakırc1, 2010), akademisyen yetersizliği (Karakütük, Aydın, Abalı ve Yıldırım, 2008), öğrenimde kalite problemleri (Bozan, 2012), politik endişeler (Doğan, 2013), psikolojik yıldırma (Celep ve Konakl1, 2013), tükenmişlik (Akbulut, Şahin ve Çepni, 2013), altyapı problemleri (Aslan, 2007), zaman ve para sorunları (Güven ve Tunç, 2007) ve öğrenci kaybı (Ertem, 2018) gibi problemler dikkat çekmektedir. Diğer taraftan, yaş (Metzner ve Bean, 1987), cinsiyet (Ferreira, 1993), medeni durum (Lott, Gardner ve Powers, 2009), bölüm (Araque, Roldan ve Salgueiro, 2009), program düzeyi (Ertem ve Gökalp; 2019a) ve dönem (Long, Ferrier ve Heagney, 2006) gibi öğrenci ile ilgili değişkenler lisansüstü eğitim süreçlerini etkilemektedir.

Lisansüstü eğitimin en önemli çıtılarından biri ise ortaya koyulan tezlerdir. Tezlerin incelenmesi aynı zamanda ilgili alandaki bakış açısı ile metodolojik yönelimleri de göstermektedir. Fazlığulları ve Kurul (2013) 1986 ve 2007 yılları arasındaki eğitim bilimleri alanında Doktora tezlerini incelemiş ve tezlerin yaklaşık \%95'inin pozitif yaklaşımlarla oluşturulduğu sonucuna ulaşmıştır. Ayrıca Ozan ve Köse (2014) Eğitim Programları ve Öğretim alanındaki araştırma eğilimlerini çalışırken araştırmaların sadece yaklaşık \%6'sının nitel ve karma yöntemlerle oluşturulduğunu bulmuştur. Bu durum, lisansüstü eğitimde bütüncül bir bakış açısı ile değil belirli yönelimlerle hareket edildiğinin önemli bir göstergesidir. 


\section{Örgüt iklimi}

Günlük hayatta insanlar sürekli hava durumundan ve yaşadıkları bölgenin ikliminden bahsederler. İklim, aynı zamanda örgütler için de geçerli bir kavram olup açık iklim olumlu ilişkilerin olduğu kurumları, kapalı iklim ise olumlu ilişkilerin bulunmadığı kurumları temsil etmektedir. Hoy ve Miskel (1991) örgüt iklimini bir kurumda çalışanların iş yerleri ile ilgili paylaştıkları algı olarak tanımlamaktadır. Lunenburg ve Ornstein'e (2011) göre ise örgüt iklimi çalışma ortamının kalitesi ile ilişkilidir.

Örgüt ikliminin tarihsel gelişimi incelendiğinde ölçme çabaları dikkat çekmektedir. Örgüt iklimi endüstriyel alanlar için önemli olmasına rağmen örgüt iklimini ölçmeye yönelik ilk adımlar eğitim bilimleri alanında atılmıştır (Hoy, Tarter ve Kottkamp, 1991). Halpin ve Crof (1963) ilköğretim okullarında örgüt iklimini “Örgüt İklimi Betimleme Ölçeği” ile ölçmüş ve öğretmenler için dört, okul müdürleri için dört olmak üzere toplam sekiz davranış ortaya çıkarmıştır. Ayrıca bir kurum için altı tip örgüt iklimi türü önermekle birlikte bunlar açık iklimden kapalı iklime doğru süreklilik içindedir. Açık iklim enerji ve yaşam dolu, tatmin edici ve insanların amaçlarını başarabildikleri kurumlarda görünürken kapalı iklim ise düşük güven ortamı ve kimsenin tatmin olmadığı kurumlarda ortaya çıkmaktadır. 1980'li yıllar itibariyle de değişik türdeki örgütler, kurumlarının iklimini ölçmeye ağırlık vermişlerdir. Örneğin Welsch ve LaVan (1981) sağlık kurumlarındaki iklimi ölçmeye yönelik çalışma yürütmüşken Moran ve Volkwein (1988) ise yükseköğretim kurumlarındaki iklimi ölçmeyi denemiştir.

Örgüt iklimi yükseköğretimde sıkça çalışılan konulardan biridir. Coso ve Sekayi (2015) lisansüstü eğitim veren kurumlarda örgüt iklimini araştırmış ve Doktora öğrencilerinin kariyer planlamaları ile profesyonel gelişimlerinin örgüt ikliminden etkilendiğini bulmuştur. Schneider, Brief ve Guzzo (1996) örgüt iklimini değişim süreciyle ilişkilendirmiş ve tek bir iklim yerine birden fazla tür iklim barındıran kurumlarda sürdürülebilir değişimin daha kolay gerçekleşebileceğine işaret etmişlerdir. Yüceler (2009) Türkiye'deki yükseköğretim kurumlarındaki örgüt iklimini incelemiş ve örgüt ikliminin örgütsel politikaları, yönetici tutumlarını, fiziksel çalışma ortamını ve sosyal ilişkileri içerdiğini ve aynı zamanda örgütsel bağl1lığı șekillendirdiğini bulmuştur.

Türkiye'de lisansüstü eğitim normal lisans eğitiminden farklı dinamikler barındırmasına rağmen, yükseköğretim iklimi kapsamında değerlendirildiği için lisansüstü eğitime özgü nitelikler değerlendirme dışı kalabilmektedir. Örneğin, öğrencinin tez danışmanı ile ilişkisi, bölüm tarafından araştırma desteği sunulması gibi hususlar lisans eğitiminde görülmeyen ya da yüzeysel kalan konular iken lisansüstü eğitimin temel omurgasını oluşturmaktadır. Ama ne yazık ki yükseköğretimde örgüt iklimi kavramı bu ayrım yapılmadan incelenmektedir. Lisansüstü eğitimde örgüt iklimini araştıran birkaç çalışma bulunmaktadır. Ertem (2018) lisansüstü eğitimde öğrenci kaybını araştırdığı Doktora tez çalışmasında örgütsel iklimin okuldan ayrılma niyetlerine örgütsel bağl1lık üzerinden dolaylı olarak etkilerini bulmuştur. Ayrıca Ertem ve Gökalp (2019b) lisansüstü eğitimde örgüt iklimini ölçen bir ölçek geliştirmişlerdir.

\section{Çalışmanın önemi}

Lisansüstü eğitimle ilgili yapı ve süreçlerin ortaya çıkarılması birçok açıdan önem kazanmaktadır. Türkiye'de yükseköğretim alanında yürütülen çalışmaların uluslararası düzeyde değerli ve anlamlı bulunan konuların Türkiye koşullarında sınanması üzerine olduğu görülmektedir. Ayrıca yürütülen çalışmaların ya yükseköğretim sisteminin yapısal sorunlarını ele aldığı ya da süreç ve çıktılarla ilgili sınırlı sayıda değişkeni incelediği görülmektedir. Bu durum Lisansüstü öğretimi çalışan araştırmaların da odağını etkilemiş ve araştırmaların daha ziyade belirli problemlere yoğunlaştı̆̆1 görülmüş̧ür. Lisansüstü eğitimde yap1 ve süreçleri bütüncül bir açıyla irdeleyen bir çalışmaya rastlanılmamıştır. Hâlbuki örgüt ikliminin lisansüstü eğitimde birçok yapı ve süreci kapsadığ1 söylenebilse de bu yap1 ve süreçleri ortaya çıkarmaya yönelik olarak lisansüstü eğitimde örgüt iklimini temel alan bir çalışma bulunmamaktadır. Diğer taraftan araştırmaların genellikle nicel ve tek bir yaklaşımla yürütüldüğü görülmekte, bu durum da karma yöntemlerle alan yazının zenginleştirilmesi ile ilgili gerçeği ve ihtiyacı ortaya koymaktadır. Sonuç olarak, alan 
yazın araştırma açısından lisansüstü eğitimle ilgili tüm yapı ve süreçlere dair bütüncül bir bakış açısı sunan ve bunu karma yöntemle uygulamaya koyan bir çalışma ile zenginleşmiş olacaktır.

Uygulama boyutunda; politika yapıcılar ve yükseköğretim kurumlarının, lisansüstü eğitimin kalitesinin artırılması, akademisyen yetiştirme politikaları ve araştırma kapasitelerinin geliştirilmesi gibi alanlarda strateji belirlemelerine zemin hazırlayacaktır. Ayrıca yükseköğretim paydaşları proje sonunda ortaya çıkacak ürünü kullanarak lisansüstü eğitim yap1 ve sürecine dair büyük resmi görebilecek ve karar verme ve geri bildirim mekanizmalarında önemli bir gösterge olarak kullanabileceklerdir. Kuramsal olarak ise çalışma sonucunda lisansüstü eğitimin yapı ve süreçlerinin örgüt iklimi ve kişilerin deneyimleri ile ilişkilendirilmesi yeni kuramsal yönelimlere 1şık tutacaktır.

\section{Çalışmanın amacı}

$\mathrm{Bu}$ çalışma lisansüstü eğitim alan öğrencilerin örgüt iklimi algılarının belirli değişkenlere göre farklılaşmasını inceleyerek lisansüstü eğitimin yap1 ve süreçlerini ortaya çıkarmayı amaçlamaktadır. Bu bağlamda çalışmanın araştırma soruları şu şekildedir:

1. Lisansüstü öğrencilerin örgüt iklimi algıları onların yaşına göre farklılaşmakta mıdır?

2. Lisansüstü öğrencilerin örgüt iklimi algıları onların akademik alanlarına göre farklılaşmakta midır?

3. Lisansüstü öğrencilerin örgüt iklimi algıları onların cinsiyetleri ve medeni durumlarına göre farklılaşmakta mıdır?

4. Lisansüstü öğrencilerin örgüt iklimi algıları onların program düzeyi ile dönemlerine göre farklılaşmakta mıdır?

5. Lisansüstü eğitim alan öğrenciler lisansüstü eğitime nasıl bir anlam yüklemektedir?

6. Lisansüstü eğitimde gözlenen yapı ve süreç değişkenleri nelerdir?

\section{Yöntem}

Çalışmanın araştırma deseni karma yöntemdir. Karma yöntem sadece yöntemi değil, problem cümlesinden sonuçların tartışılmasına kadar tüm bilimsel süreçleri karmalar (Teddlie ve Tashakkori, 2003). Karma çalışmalarda hem nicel hem nitel araştırma desenleri kullanılır. Bu çalışmada karma yöntem türlerinden çeşitleme deseni kullanılmıştır. Bu desende tek bir olgu eşit öneme sahip hem nicel hem de nitel yöntemle çalışılmaktadır. Aynı anda iki desenin kullanılması bir diğerinin dezavantajını ortadan kaldırarak daha güçlü sonuçlar ve çıkarımlar yapılmasına katkı sağlar (Creswell, 2012). Çalışmanın nicel boyutunda nedensel-karşılaştırma ve nitel boyutunda olgu-bilim deseni kullanılmıştır. Nedensel-karşılaştırma kısmında lisansüstü öğrencilerin örgüt iklimi algılarına etkisi olan değişkenler sınanırken olgu-bilim çalışmasında onların lisansüstü eğitim hayatındaki deneyimleri araştırılmıştır Nicel kısımda bağımlı değişken örgüt iklimi algısı iken; bağımsız değişkenler ise cinsiyet, medeni durum, yaş, bölüm, program düzeyi ve dönemdir. Nitel araştırmada ana temalar akademik, sosyal, kültürel ve yönetimsel olarak düşünülmüştür.

Bağımlı ve bağımsız değişkenin seçilme nedenleri tamamı ile lisansüstü eğitimdeki yapı ve süreçlere ilişkindir. Örgüt iklimi kavramı, akademik gelişimden sosyal etkileşime kadar lisansüstü eğitimde gözlenen birçok dinamiği kapsamaktadır. Diğer taraftan, cinsiyet, medeni durum, yaş, bölüm, program düzeyi ve dönem öğrencilerin lisansüstü eğitime başlama nedenlerinden mezuniyet durumuna kadar birçok süreçte etkili olan faktörlerdir.

\section{Evren ve örneklem}

Çalışmanın evreni araştırma üniversitelerindeki lisansüstü öğrenciler olacaktır. Yükseköğretim Kurulu Başkanlığı'nın istatistik veri tabanına göre (2018) araştırma üniversitelerinde (Ankara, Boğaziçi, Erciyes, Gazi, Gebze Teknik, Hacettepe, Istanbul, İstanbul-Cerrahpaşa, Istanbul Teknik ve Orta Doğu Teknik Üniversiteleri ile İzmir Yüksek Teknoloji Enstitüsü) toplam 112651 lisansüstü öğrenci kayıtlıdır. Tablo 1 araştırma üniversiteleri ile ilgili bilgi sunmaktadır. 
Tablo 1.

Evren

\begin{tabular}{lllll}
\hline Üniversite & Lisansüstü Öğrenci Sayısı (YL, DR) & $\begin{array}{l}\text { Öğrenci/Öğretim } \\
\text { Üyesi }\end{array}$ & $\begin{array}{l}\text { Doktora } \\
\text { Ögrenci } \\
\text { Oran1 }\end{array}$ & $\begin{array}{l}\text { Mezun } \\
\text { Doktor } \\
\text { Say1s1 }\end{array}$ \\
\hline $\begin{array}{l}\text { Ankara } \\
\text { Üniversitesi }\end{array}$ & $14062(8810,5252)$ & 29.47 & 0.11 & 414 \\
$\begin{array}{l}\text { Boğaziçi } \\
\text { Unniversitesi }\end{array}$ & $4457(3161,1296)$ & 32.76 & 0.09 & 71 \\
$\begin{array}{l}\text { Erciyes } \\
\text { Üniversitesi }\end{array}$ & $8013(6456,1557)$ & 33.63 & 0.04 & 118 \\
$\begin{array}{l}\text { Gazi } \\
\text { Üniversitesi }\end{array}$ & $16862(12002,4860)$ & 35.42 & 0.08 & 409 \\
$\begin{array}{l}\text { Gebze Teknik } \\
\text { Üniversitesi }\end{array}$ & $4772(3959,813)$ & 27.95 & 0.13 & 60 \\
$\begin{array}{l}\text { Hacettepe } \\
\begin{array}{l}\text { Universitesi } \\
\text { Istanbul }\end{array}\end{array}$ & $12380(8187,4193)$ & 25.73 & 0.09 & 317 \\
$\begin{array}{l}\text { Universitesi } \\
\begin{array}{l}\text { Istanbul Teknik } \\
\text { Üniversitesi }\end{array}\end{array}$ & $14759(11042,3717)$ & 33.27 & 0.08 & 441 \\
$\begin{array}{l}\text { Izmir Yüksek } \\
\text { Teknoloji Ens. }\end{array}$ & $1713(1257,416)$ & 34.84 & 0.10 & 173 \\
$\begin{array}{l}\text { Orta Doğu } \\
\text { Teknik Üni. }\end{array}$ & $8251(5053,3198)$ & 24.38 & 0.10 & 21 \\
\hline \begin{tabular}{l} 
Toplam \\
\hline Ortalama
\end{tabular} & 112651 & 33.11 & 0.12 & 245 \\
\hline & 11265.1 & 310.56 & - & 2269 \\
\hline
\end{tabular}

Örneklem seçiminde ilk aşamada bu üniversitelerin hepsinde ortak olan lisansüstü alanlar seçilmiştir. Bu alanlar eğitim bilimleri, sosyal bilimler, fen bilimleri ve sağlık bilimleridir. (Güzel sanatlar, tıp, diş hekimliği, veterinerlik ve eczacılık farklı bir lisansüstü yapısına sahip olduğu için kapsam dışına çıkarılmıştır). İkinci aşamada çalışma izni gönderilen üniversiteler (İstanbul Teknik Üniversitesi, Ankara Üniversitesi, Gazi Üniversitesi, Orta Doğu Teknik Üniversitesi, Erciyes Üniversitesi ve İzmir Yüksek Teknoloji Enstitüsü) ziyaret edilmiştir. Tablo 1'deki öğrenci sayıları ve diğer ortalamalar dikkate alındığında çalışma izni veren 6 üniversite evren temsiliyetini sağlamaktadır (10600 öğrenci ortalaması, 31,80 öğrenci başına düşen öğretim üyesi ortalaması, 0,10 Doktora öğrenci oranı ortalamas1 ve 230 doktora mezun ortalamas1). Bu üniversitelerde iki adımlı rast gele örnekleme yöntemi ile çalışmaya gönüllü olarak katılmak isteyen 448 öğrenciye ulaşılmıştır. Önce yukarıda bahsedilen temel alanlarda zorunlu derslerin listesi çıkarılmış ve bu listeden rast gele dersler seçilerek derse katılım sağlayan tüm öğrencilere ölçek dağıtılmıştır. Katılımcıların 442'si sağlıklı veri sağlamıştır. Tablo 2 örneklemle ilgili demografik bilgileri sunmaktadır. Çalışmanın nitel boyutu içinse kartopu örneklem türüne başvurulmuş ve nicel veri sağlayan 442 öğrenciden 8'i de görüş̧meye katılım sağlamıştır.

Tablo 2.

Örneklem

\begin{tabular}{llll}
\hline Değişken & & Frekans & Yüzdelik(\%) \\
\hline Cinsiyet & Kadın & 257 & 58.1 \\
& Erkek & 185 & 41.9 \\
Yaş & 22 ve altı & 9 & 2 \\
& $23-28$ & 320 & 72.4 \\
& $29-34$ & 98 & 22.2 \\
\multirow{3}{*}{ Medeni durum } & $35+$ & 15 & 3.4 \\
& Evli & 73 & 16.5 \\
& Bekâr & 369 & 83.5
\end{tabular}




\begin{tabular}{llll} 
Akademik alan & Eğitim Bilimleri & 124 & 28.1 \\
& Sosyal Bilimler & 131 & 29.6 \\
& Fen Bilimleri & 121 & 27.4 \\
& Sağllk Bilimleri & 66 & 14.9 \\
\multirow{2}{*}{ Program düzeyi } & Yüksek Lisans & 335 & 75.8 \\
& Doktora & 107 & 24.2 \\
Dönem & Ders & 375 & 84.8 \\
& Tez & 67 & 15.2 \\
\hline Toplam & & 442 & 100 \\
\hline
\end{tabular}

\section{Veri toplama}

Ölçek 5 bölümden oluşmakta olup ilk kısımda demografik, ikinci bölümde finansal destek yolu, üçüncü bölümde lisansüstü eğitime başlama nedenleri, dördüncü bölümde memnuniyet alanları ve son bölümde ise örgüt iklimi ile ilgili sorular bulanmaktadır.

Örgüt Ikklimi Ölçeği: Beşli likert tipinde 28 madde 6 boyutta toplanmıştır. Boyutlar, akademik iklim, sosyal iklim, bölüm iklimi, yönetimsel iklim, öğretim üyeleriyle ilişkiye dayalı iklim ve danışmanla ilişkiye dayalı iklimdir. Ertem ve Gökalp (2019b) tarafından geliştirilen bu ölçeğin Cronbach Alfa güvenirlik katsayısı .87 olmakla birlikte boyutların güvenirlik katsayıları .70 ile .85 arasında değişmektedir. Altı boyutlu yapı toplam varyansın \%57.39'unu açıklamıştır. Bu yapının faktör yükleri ise .28 ile .90 arasında değişmektedir. Ölçek araştırma üniversitelerinde lisansüstü eğitim gören öğrencilere uygulanarak geçerliği ve güvenirliği ispatlanmıştır. Ölçeğin kullanılması için araştırmacılardan gerekli izinler alınmıştır. Ölçeğin bu çalışmadaki katılımcılara uygulanması sonucu ölçek boyutları sosyal iklim .78, öğretim üyeleriyle ilişkiye dayalı iklim .72, danışmanla ilişkiye dayalı iklim .84, akademik iklim .76, bölüm iklimi .69 ve yönetimsel iklim .75 Cronbach Alfa iç tutarlılık katsayıları göstermiştir.

Görüşme formu: Nitel veriyi toplamak içinse ölçekteki maddeler, alan yazındaki fikirler ve yükseköğretim süreçleri göz önüne alınarak altı ana soru ile 15 tane alt sorudan oluşan, yarı yapılandırılmış bir görüşme formu hazırlanmıştır. Akademik, sosyal, kültürel ve yönetimsel süreçlerde katılımcıların deneyimlerini ortaya çıkarmaya yönelik sorular bulunmaktadır. "Lisansüstü eğitime başlamaya nasıl karar verdiniz?", "Lisansüstü eğitimde sizi en fazla memnun eden durumlar nelerdir?" ve "Lisansüstü eğitimde sizi neler hayal kırıklığına uğrattı?" görüşme sorularına örnek olarak gösterilebilir. Üç öğretim üyesinden uzman görüşü alınarak ve soruların anlaş1lırlığını kontrol etmek için de iki lisansüstü öğrenci ile bilişsel görüşmelere yapılarak bazı alt sorular eklenmiş ve soruların yapısı değiştirilmiştir. Katılımcının geçmişi, lisansüstü eğitime başlama sebepleri, lisansüstü eğitim memnuniyeti, akademik etkinliklere katılım, lisansüstü eğitim avantajları ve çözüm önerileri şeklinde altı tane ana soru belirlenmiştir. Diğer taraftan

Doküman analizi: YÖK web sitesindeki bilgi ve belgeler incelenmiştir. Bunun için lisansüstü eğitimle ilgili yapı ve süreç değişkenlerine ilişkin bir tarama yapılmıştır. Ortaya çıkan değişkenler girdi, süreç, çıktı ve geribildirim değişkenleri olarak sıralanmıştır.

\section{İşlem}

Etik onaydan sonra kurumsal izin süreci başlatılmış ve izin gönderen altı üniversite saha çalışması için ziyaret edilmiştir. Araştırmacı veri toplama sürecini kendisi yönetmiş olup bazı durumlarda öğretim elemanları ile randevulaşarak sınıflardaki öğrencilere ölçeği uygulamıştır. Çalışmaya katılımcı davet etmeden önce çalışmanın amacı ve önemi hakkında açıklama yapılmış ve gönüllülük ilkesi vurgulanmıştır. Gönüllü katılım sağlayacaklara gönüllü katılım formu ve ölçek birlikte dağıtılmıştır. Katılımcılar anketi bitirdiklerinde gönüllü katılım formunu imzalamaları istenmiş ve yarım saatlik bir görüşmeye zaman ayırıp ayıramayacakları sorulmuştur. Çalışmada ölçeği dolduran 448 öğrenciden sekizi görüşme için de gönüllü olmuş ve gün içinde uygun bir anda görüşme yapılmıştır. Görüşmeye katılan öğrencilerden de ayrıca gönüllü katılım formunun 
imzalanması rica edilmiştir. Bu makalenin tüm safhalarında araştırma ve yayın etiğine uyulmuş olup ZBEÜ İnsan Araştırmaları Etik Kurulu'nun 27.06.2019 tarihli ve 597 nolu onayı vardır.

\section{Verilerin analizi}

Ön analizler sonucunda 448 anketin 6 tanesi eksik veri nedeniyle analiz dışına çıkarılmıştır. Ölçeklerden elde edilen veriler betimsel ve çıkarımsal istatistiğe tabi tutulmuştur. Betimsel analiz istatistik ortalamalar ve frekanslar ile sunulmuştur. Çıkarımsal istatistikle ise bağımsız değişkenlerin bağımlı değişken üzerindeki etkisi incelenmiştir. Yaş ve bölümün örgüt iklimi algısına etkisi tek yönlü varyans analizi ile incelenirken medeni durumun cinsiyetle ve program düzeyinin dönemle birlikte örgüt iklimine etkisi ise çift yönlü varyans analizi ile incelenmiştir. $\mathrm{Bu}$ analizler anlamlılık düzeyi .05 olarak kabul edilmiştir.

Görüşme sorularından elde edilen veriler içerik analizine tabi tutulmuş ve akademik, sosyal, kültürel ve yönetimsel deneyimleri ifade edecek kodlar ve temalar ortaya çıkarılmıştır. Ortak temalar ve kodlar üzerinden frekans tabloları oluşturulmuş ve bulgular doğrudan alıntılarla desteklenmiştir. Ayrıca nicel ve nitel veriyi desteklemek için doküman analizi yapılmış ve tüm sonuçlar harmanlanarak tablo yoluyla betimlenmiştir.

\section{Bulgular}

Çalışmanın betimsel analiz sonuçlarına göre düzenli geliri olan öğrencilerin sayısı $(n=301)$ geliri olmayanlarınkinden $(n=141)$ fazladır. Katılımcıların lisansüstü eğitime başlama nedenleri sırasıyla akademisyen olma $(n=398)$, kişisel ve mesleki gelişim $(n=327)$, görevde yükselme ve promosyon $(n=96)$, tavsiye $(n=87)$, farklı alana ilgi $(n=32)$ ve kariyer belirsizliğidir $(n=29)$. Katılımcıların en fazla memnun olduğu üç lisansüstü deneyim akademik gelişim $(n=87)$, program yapısı ve işleyiş $(n=87)$ ve hedeflere ulaşma $(n=87)$ ile ilgiliyken en az memnun olunan üç lisansüstü deneyim ise eğitim ve iş arasındaki denge, ekonomik kaynak $(\mathrm{n}=87)$ ve bürokratik süreçlerdir $(\mathrm{n}=87)$.

Tablo 3.

Örgüt İklimi Boyutlarına İlişkin Ortalama ve Standart Sapma Değerleri

\begin{tabular}{lll}
\hline Değişken & Ortalama & Standart Sapma \\
\hline Akademik iklim & 4.47 & .50 \\
Danı̧man ile ilişkili iklim & 4.26 & .76 \\
Öğretim üyesi ile ilişkili iklim & 4.22 & .60 \\
Sosyal iklim & 4.10 & .59 \\
Bölüm iklimi & 3.68 & .68 \\
Yönetimsel iklim & 3.62 & .80 \\
\hline
\end{tabular}

Katılımcıların örgüt iklimi algılarının yüksek düzeyde olumlu $(\bar{X}=4.08, S S=.42)$ olduğu görülmektedir. Ayrıca örgüt iklimi algısının boyutlarına göre hesaplamalar yapıldığında en olumlu iklim algısının akademik iklimde $(\bar{X}=4.47, S S=.50)$; en olumsuz iklim algısının ise yönetimsel iklimde $(\bar{X}=3.62, S S=.80)$ olduğu görülmektedir. Diğerleri ise sırasılyla danışman ile ilişkili iklim $(\bar{X}=4.26, S S=.76)$, öğretim üyesi ile ilişkili iklim $(\bar{X}=4.22, S S=.60)$, sosyal $i k \lim (\bar{X}=4.10, S S=.59)$ ve bölüm iklimdir $(\bar{X}=3.68, S S=.68)$. Tablo 3 boyutların ortalama ve standart sapma değerlerini göstermektedir.

Çalışmanın birinci araştırma sorusu olan örgüt iklimi algısının yaşa göre farklılaşıp farklılaşmadığını cevaplayabilmek için 442 katılımcıdan toplanan veri tek yönlü ANOVA analiz edilmiştir. Temel analiz öncesi bağımsız gözlem, normallik ve varyans homojenliği varsayımları (Gravetter ve Wallnau, 2013) kontrol edilmiştir. Bağımsız gözlemin katılımcıların ölçeği tek başına doldurduğu gözlemleriyle, normalliğin histogram ve Q-Q şekilleriyle ve varyans homojenliğinin ise Levene testinin anlamsız çıkmasıyla doğrulandığı görülmüştür. 
Tablo 4.

Yaş Grubuna İlişkin Tek Yönlü Varyans Analizi Sonuçları

\begin{tabular}{llllll}
\hline Kaynak & $S S$ & $d f$ & $M S$ & $F$ & $\eta_{2}$ \\
\hline Yaş & 1.65 & 3 & .55 & $3.12 *$ & .02 \\
Hata & 77.18 & 438 & .18 & & \\
Toplam & 78.82 & 441 & & & \\
\hline * & & & &
\end{tabular}

$* p<.05$

Tek yönlü ANOVA sonuçları yaş grupları bazında örgüt iklimi algılarında anlamlı bir farkl11ık olduğunu göstermiştir, $F_{(3,438)}=3.12, p<.05, \eta_{2}=.02$. Örgüt iklimi algısındaki varyansın \%2'si yaş grubundaki farklllıklardan meydana gelmekte olup bu sonuç Cohen (1992) standartlarına göre küçük etki büyüklügüne denk gelmektedir. Analiz sonuçları Tablo 4'te verilmiştir.

Tablo 5.

Yaş Grubuna İlişkin Scheffe Testi Sonuçları

\begin{tabular}{llll}
\hline Test & Yaş grubu & Yaş grubu & Ortalama Fark1 \\
\hline Scheffe & 22 ve altı & $23-28$ & .02 \\
& $29-34$ & .15 \\
& 35 ve üstü & .17 \\
& $23-28$ & 22 ve altı & -.02 \\
& $29-34$ & $.14^{*}$ \\
& 35 ve üstü & .15 \\
& $29-34$ & 22 ve altı & -.15 \\
& $23-28$ & $-.14^{*}$ \\
& 35 ve üstü & .02 \\
& 22 ve altı & -.17 \\
& $23-28$ & -.15 \\
& $29-34$ & -.02 \\
\hline
\end{tabular}

$* p<.05$

Yaş gruplarının hangileri arasında anlamlı farklar olduğunu incelemek içinse Post Hoc testlerinden Scheffe testi analiz edilmiștir ve 23-28 yaș grubundakilerin örgüt iklimi algılarının $(\bar{X}=4.11, S S=.39), 29-34$ yaş grubundakilerinden $(\bar{X}=3.98, S S=.50)$ anlamlı olarak daha yüksek olduğu bulunmuştur. Tablo 5 Scheffe testi sonuçlarını göstermektedir.

Çalışmanın ikinci araştırma sorusu olan örgüt iklimi algısının akademik alana göre farklılaşıp farklılaşmadığını cevaplayabilmek için katılımcılardan toplanan veri tek yönlü ANOVA analiz edilmiştir. Temel analiz öncesi bağımsız gözlem, normallik ve varyans homojenliği varsayımları (Gravetter ve Wallnau, 2013) kontrol edilmiştir. Bağımsız gözlemin katılımcıların ölçeği tek başına doldurduğu gözlemleriyle, normalliğin histogram ve Q-Q şekilleriyle ve varyans homojenliğinin ise Levene testinin anlamsız çıkmasıyla doğrulandığ 1 görülmüştür.

Tablo 6.

Akademik Alan İlişkin Tek Yönlü Varyans Analizi Sonuçları

\begin{tabular}{llllll}
\hline Kaynak & SS & df & MS & F & $\eta_{2}$ \\
\hline Akademik Alan & 3.37 & 3 & 1.12 & $6.52 *$ & .04 \\
Hata & 75.46 & 438 & .17 & & \\
Toplam & 78.82 & 441 & & & \\
\hline
\end{tabular}

$* p<.05$ 
Tek yönlü ANOVA sonuçları akademik alanlar bazında örgüt iklimi algılarında anlamlı bir farklılık olduğunu göstermiştir, $\mathrm{F}_{(3,438)}=6.52, \mathrm{p}<.05, \eta_{2}=.04$. Örgüt iklimi algısındaki varyansın \%4'ü akademik alandaki farklılıklardan meydana gelmekte olup bu sonuç Cohen (1992) standartlarına göre neredeyse orta düzeyde etki büyüklügüne denk gelmektedir. Analiz sonuçları Tablo 6'da verilmiş̧ir.

Tablo 7.

Akademik Alana İlişkin Scheffe Testi Sonuçları

\begin{tabular}{llll}
\hline Test & Akademik Alan & Akademik Alan & Ortalama Fark1 \\
\hline Scheffe & Eğitim Bilimleri & Sosyal Bilimler & .13 \\
& & Fen Bilimleri & .12 \\
& Sağllk Bilimleri & -.11 \\
& Sosyal Bilimler & Eğitim Bilimleri & -.13 \\
& Fen Bilimleri & -.01 \\
& Sağllk Bilimleri & $-.24^{*}$ \\
& Fen Bilimleri & Eğitim Bilimleri & -.12 \\
& Sosyal Bilimler & .01 \\
& Sağlik Bilimleri & $-.23^{*}$ \\
& Sağlık Bilimleri & Eğitim Bilimleri & .11 \\
& Sosyal Bilimler & $.24^{*}$ \\
& Fen Bilimleri & $.23^{*}$ \\
\hline
\end{tabular}

$* p<.05$

Akademik alanların hangileri arasında anlamlı farklar olduğunu incelemek içinse Post Hoc testlerinden Scheffe testi yürütülmüştür. Sağlık bilimlerindeki lisansüstü öğrencilerinin örgüt iklimi algilarının $(\bar{X}=4.24, S S=.44)$, hem fen bilimlerindekinden $(\bar{X}=4.01, S S=.40)$, hem de sosyal bilimlerindekinden $(\bar{X}=4.00, S S=.41)$, anlamlı olarak daha yüksek olduğu bulunmuştur. Tablo 7 Scheffe testi sonuçlarını göstermektedir.

Çalışmanın üçüncü araştırma sorusu olan örgüt iklimi algılarının cinsiyet ve medeni duruma göre farklılaşıp farklılaşmadığını cevaplayabilmek için katılımcılardan toplanan veri çift yönlü ANOVA analiz edilmiştir. Temel analiz öncesi bağımsız gözlem, normallik ve varyans homojenliği varsayımları (Gravetter ve Wallnau, 2013) hem cinsiyet ve medeni durum için ayrı ayrı hem de etkileşimlerini hesaba katarak kontrol edilmiştir. Bağımsız gözlemin katılımcıların ölçeği tek başına doldurduğu gözlemleriyle, normalliğin histogram ve Q-Q şekilleriyle ve varyans homojenliğinin ise Levene testinin anlamsız çıkmasıyla doğrulandığı görülmüştür.

Tablo 8.

Cinsiyet ve Medeni Duruma İlişkin Çift Yönlü Varyans Analizi

\begin{tabular}{llllll}
\hline Kaynak & $\mathrm{SS}$ & $\mathrm{df}$ & $\mathrm{MS}$ & $\mathrm{F}$ & $\eta_{2}$ \\
\hline Cinsiyet & .47 & 1 & .47 & 2.68 & .00 \\
Medeni Durum & 1.79 & 1 & 1.79 & $10.28^{*}$ & .02 \\
Cinsiyet*Medeni Durum & .00 & 1 & & & \\
Hata & 76.08 & 438 & & & \\
Toplam & 78.82 & 441 & & & \\
\hline$* 0.05$ & & & & &
\end{tabular}

Çift yönlü ANOVA sonuçları cinsiyet ve medeni durum etkileşimi boyutunda örgüt iklimi algılarında anlamlı bir farklılık göstermemiştir, $\mathrm{F}_{(1,441)}=.00, \mathrm{p}>.05$. Etkileşimin anlamsız çıkması bağımsız değişkenlerin ayrı ayrı ana etkilerinin incelenmesi gerektiği gerçeğini ortaya koymuştur. ANOVA sonuçları cinsiyet için anlamlı bulunmazken, $\mathrm{F}_{(1,441)}=2.68, \mathrm{p}>.05$; medeni durum bazında örgüt iklimi algılarında anlamlı bir farklılık olduğunu göstermiştir, $\mathrm{F}_{(1,441)}=10.29$, $\mathrm{p}<.05, \eta_{2}=.02$. Örgüt iklimi algısındaki varyansın $\% 2$ 'si medeni durumdaki farklılıklardan 
meydana gelmekte olup bu sonuç Cohen (1992) standartlarına göre küçük etki büyüklügüne denk gelmektedir. Analiz sonuçları Tablo 8'te verilmiştir. Bekâr lisansüstü öğrencilerinin örgüt iklimi algılarının $(\bar{X}=4.11, S S=.39)$ evli ögrencilerinkinden $(\bar{X}=3.93, S S=.53)$ anlamlı olarak daha yüksek olduğu bulunmuştur.

Çalışmanın dördüncü araştırma sorusu olan örgüt iklimi algısının program düzeyi ve döneme göre farklılaşıp farklılaşmadığını cevaplayabilmek için katılımcılardan toplanan veri çift yönlü ANOVA analiz edilmiştir. Temel analiz öncesi bağımsız gözlem, normallik ve varyans homojenliği varsayımları (Gravetter ve Wallnau, 2013) hem program düzeyi ve dönem için ayrı ayrı hem de etkileşimlerini hesaba katarak kontrol edilmiştir. Bağımsız gözlemin katılımcıların ölçeği tek başına doldurduğu gözlemleriyle, normalliğin histogram ve Q-Q şekilleriyle ve varyans homojenliğinin ise Levene testinin anlamsız çıkmasıyla doğrulandığı görülmüştür.

Tablo 9.

Program Düzeyi ve Döneme İlişkin Çift Yönlü Varyans Analizi

\begin{tabular}{llllll}
\hline Kaynak & $S S$ & $\mathrm{df}$ & $\mathrm{MS}$ & $\mathrm{F}$ & $\eta_{2}$ \\
\hline Program Düzeyi & .71 & 1 & .71 & $4.00^{*}$ & .01 \\
Dönem & .02 & 1 & .02 & .10 & .00 \\
Program Düzeyi*Dönem & .06 & 1 & & & \\
Hata & 77.96 & 438 & & & \\
Toplam & 78.82 & 441 & & & \\
\hline *p<.05 & & & &
\end{tabular}

Çift yönlü ANOVA sonuçları program düzeyi ve dönem etkileşimi boyutunda örgüt iklimi algılarında anlamlı bir farklılık göstermemiştir, $\mathrm{F}_{(1,441)}=.33, \mathrm{p}>.05$. Etkileşimin anlamsız çıkması bağımsız değişkenlerin ayrı ayrı ana etkilerinin incelenmesi gerektiği gerçeğini ortaya koymuştur. ANOVA sonuçları dönem için anlamlı bulunmazken, $F_{(1,441)}=.10, p>.05$; program düzeyi bazında örgüt iklimi algılarında anlamlı bir farklılık olduğunu göstermiştir, $\mathrm{F}(1,441)=4.00$, $\mathrm{p}<.05, \eta_{2}=.01$. Örgüt iklimi algısındaki varyansın $\% 1$ 'i program düzeyindeki farklılıklardan meydana gelmekte olup bu sonuç Cohen (1992) standartlarına göre küçük etki büyüklügüne denk gelmektedir. Analiz sonuçları Tablo 9'da verilmiştir. Yüksek lisans öğrencilerinin örgüt iklimi algılarının $(\overline{\mathrm{X}}=4.10, \mathrm{SS}=.41)$ doktora öğrencilerinkinden $(\overline{\mathrm{X}}=4.00, \mathrm{SS}=.45)$ anlamlı olarak daha yüksek olduğu bulunmuştur.

Çalışmanın beşinci araştırma sorusu olan lisansüstü öğrencilerinin lisansüstü eğitime nasıl bir anlam yüklediklerini öğrenmek için sekiz öğrenci ile görüşme yapılmıştır. Katılımcının geçmişi, lisansüstü eğitime başlama sebepleri, lisansüstü eğitim memnuniyeti, akademik etkinliklere katılım, lisansüstü eğitim avantajları ve çözüm önerilerine odaklanan görüşme sorularından elde edilen veriler içerik analizine tabi tutulmuştur. Ortaya çıkan kodların benzerlikleri ve farklılıkları dikkate alınarak akademik, sosyoekonomik, kültürel ve yönetimsel temalar belirlenmiştir.

Akademik deneyimler teması dikkate alındığında akademisyen olma isteği, kişisel ve akademik gelişim lisansüstü eğitime başlama nedenleri olarak gösterilmektedir. Öğrencilerin hepsi lisansüstü eğitime kabul kriterleri olan Akademik Personel ve Lisansüstü Eğitim Sınavı (ALES), Yabanc1 Dil Sinavı (YDS), not ortalaması ve mülakatın ya da yazılı sınavın gerekli olduğunu belirtmişler ama toplam puana oranları noktasında görüş ayrılıklarına sahiptirler. Örneğin fen bilimleri öğrencileri not ortalaması ağırlığının daha düşük olması gerektiğini dile getirirken sosyal bilimler öğrencileri ise ALES sınavının ağırlı̆̆ının daha düşük olması gerektiğini vurgulamışlardır. Ders içeriği ve ödevler akademik gelişim için öğrencilerin memnun olduğu deneyimlerken seçmeli ders sayısının düşük olması ve kuramın uygulamaya aktarılmasındaki sıkıntılar öğrencilerin memnun olmadığı deneyimlerdir. Hem olumlu hem de olumsuz deneyimleri olan $\mathrm{K} 7$ şunları paylaşmıştır: 
"Ben buraya gelmeden önce hocaların özgeçmişlerini okudum ve daha mülakata bile girmeden çok kaliteli bir yer olduğunu ögrenmiştim. Mülakatta da bunu gördüm, hocaların yaklaşımları çok pozitifti. Ne olursun kabul edileyim diye dua ettim. Evet, puanlarım yüksekti ama diğer arkadaşlar da çok iyiydi bence. Bu tahminlerimde yanılmadı̆̆ımı kısa zamanda gördüm. Hem hocalarımla hem de arkadaşlarla birlikte çok güzel akademik etkinlikler yürüttük. Kendimi bu anlamda çok iyi yetiştirdiğimi düşünüyorum. Gerçi seçmeli ders havuzumuz daha geniş olsaydı ve ben de kendi ilgi alanıma giren dersler seçseydim daha da akademik olarak memnun olurdum. " (K7)

Sosyo-ekonomik deneyimler teması altında dikkat çeken üç husus akran ilişkisi, öğretim elemanlarıyla ilişkiler ve finansal destektir. Akran ilişkisi ve öğretim elemanlarıyla olan ilişki boyutlarından öğrencilerin deneyimlerinin genellikle olumlu olduğu görülmüsstür. Lisansüstü eğitimin maliyetlerinin karşılanması noktasında öğrencilerin memnuniyet derecelerinin düşük olduğu dikkat çekmektedir. Düzenli geliri olmayan veya aile desteği alan lisansüstü öğrenciler hayatlarını idame ettirmeleri noktasında memnuniyetsizliklerini dile getirirken düzenli geliri olan lisansüstü öğrenciler ise konferanslara katılmak için ekonomik destek bulamamaktan yakınmışlardır. Buradan hareketle öğrenciler devletin lisansüstü öğrencilere iş veya karşılıksız burs vermeleri noktasında öneriler geliştirmişlerdir. Katılımcı K3 şu yönde bir çözüm önerisi getirmiş̧ir:

"Evet, anliyorum. Devlet her alana çok sayıda araştırma görevlisi alamaz, almamalı da zaten. Ama şöyle bir şey yapabilir. Onlar da yüksek lisans öğrencisi olacağına siz kontenjanlarl sinırlı tutun. Başarll ögrenciler gelsin böylece ve sen de onlart araştırma merkezlerinde, kütüphanelerde, laboratuvarlarda ya da öyle yerlerde çalıştır. Hem üniversite işleri kolaylaşsin hem de ögrenciye destek olsun. " (K3)

Kültürel deneyimler öğrencilerin kültürel uyumları ile ilgili olup iki nokta dikkat çekmektedir. Birincisi mekânsal yer değiştirmeyle ilgili olan yeni şehre ya da yeni üniversiteye uyum olup öğrenciler bu uyumu zamanla başardıklarını dile getirmişlerdir. Diğeri ise eğitim düzeyindeki değişimden kaynaklanmakta olup öğrenciler ilk yıl ya da ilk dönemlerini lisansüstü eğitimin gerekliliklerine alışma ve görev ve sorumlulukları öğrenme ile geçirdiklerini ifade etmişlerdir. $\mathrm{Bu}$ noktada öğrenciler uzun süreli oryantasyon programları önermişlerdir. Öğrencilerin özellikle ders seçimi, danışman seçimi ve danışman ile iletişim noktasında sıkıntı yaşadıkları ortaya çıkmıştır. Öğrenciler özellikle danışmanlarıyla kültürel veya ideolojik farklılıklar olduğunu, bunun iletişime ve dolayısıyla performansa yansıdığı ve bunu önlemek için öğrencilerin danışmanları kendilerinin seçmesi gerektiğini vurgulamışlardır. Mekânsal yer değiştirmeye bağlı kültürel uyumdan ziyade lisansüstü eğitim dinamiklerine bağlı kültürel uyumun öğrencileri daha fazla zorladığ 1 görülmüştür. Katılımc1 K1 ilginç anısını şu şekilde paylaşmışır:

"Bazen hoca çatı̧̧ması oluyor. Kendi danışmanınızla ve diğer dersi aldĭ̆ınız hoca arasındaki çatışmadan öğrenci zararlı çıkıyor. Benim ders dönemimde yaşadığım sıkıntı oydu. Danışmanımla anlaşamayan bir hoca vardı ondan ders almuştım, beni finalde bıraktı ben de bütünlemede geçtim. Danışmanımı kendim seçsem belki bunları yaşamazdım, yani ona göre davranırdım." (K1)

Yönetimsel deneyimlerde dikkat çeken süreç enstitü işleyişindeki bürokratik işlemler ve bölüm dinamikleri ile ilgilidir. Özellikle enstitü ile sağlıkl iletişim kuramama, evrak işlerinin yoğun ve uzun sürmesi ve tez döneminde yeterince yönlendirme olmaması öğrencilerin olumsuz deneyimleridir. Öğrenciler, bu olumsuz deneyimleri aşmak için lisansüstü destek ofisi, enstitü destek hattı ve dijital belge yönetim sistemi önerilerini sunmuştur. Diğer taraftan ders programlarının oluşturulmasında akademik birimlerin sadece öğretim üyesi talebi ve derslik uygunluğu gibi bölüm dinamiklerini dikkat alması sonucu çalışan öğrencilerin derslere devam 
edemediği dile getirilmiştir. Bu noktada öğrenciler ders programları oluşturulurken öğrencilerin taleplerinin dikkate alınması gerektiğini önermişlerdir. Katılımcılardan K5 deneyimini şu şekilde anlatmıştır.

"Olumsuzluk demek ne kadar doğru ama ciddi bir iş yükü vardl. İş yükü çallşanlar için daha da ağırlaşıyordu. Hocalar devam konusunda da ciddiydi. Mesela ders programları şehir dışından gelen ögrencilere göre düzenlenmiyordu. Şehir dışından geliyorum bir dersim Pazartesi ve bir dersim Perşembe o gerçekten zorlayıcıydı o dönem." (K5)

Çalışmanın altıncı araştırma sorusu olan lisansüstü eğitimde yapı ve süreç değişkenlerini anlamak için doküman analizi gerçekleştirilmiştir. Forster'in (1995, Akt. Yıldırım ve Şimşek, 2016) doküman incelemesi için önerdiği beş adım uygulanmıştır. İlk olarak, YÖK sitesindeki bilgi ve belgelere ulaşılmıştır. Bu bilgi ve belgeler halka açık olup ücretsiz bir şekilde erişim mümkündür. Ardından; Yükseköğretim Kanunu ve Lisansüstü Eğitim Yönetmeliği’ne ek olarak web sitesindeki haber, duyuru ve içerikler incelenmiş ve özgünlüğü kontrol edilmiştir. Üçüncü adımda dokümanlar anlaşılmaya çalışılmıştır. Bu noktada nicel ve nitel veri toplamadan elde edilen bulgularla ulaşılan dokümanlar birbirleriyle karşılaştırılmıştır. Dördündü adımda dokümanları içerik analizine tabi tutmak için lisansüstü eğitimle ilgili olan dokümanlara odaklanılmıştır. Bu bağlamda, açık sistemin öğeleri olan girdi, süreç, çıktı ve geribildirim temaları oluşturulmuştur. Analiz birimi olarak genellikle sözcük, cümle ve paragraflar seçilmiştir ve temaların altına dağıtılmıştır. Son adımda ise doküman analizinden gelen verinin nicel ve nitel veri ile sentezlenerek kullanılması sağlanmıștır. Tablo 10 doküman analizi ile nicel ve nitel verinin analiz sonuçlarının harmanlandığı şekilde lisansüstü yapı ve süreç değişkenlerini sunmaktadır.

Tablo 10.

Lisansüstü Eğitimde Yap1 ve Süreç

\begin{tabular}{|c|c|c|c|c|}
\hline Veri & Girdi & Süreç & Ç1ktı & Geribildirim \\
\hline \multirow{12}{*}{$\begin{array}{l}\text { Doküman } \\
\text { analizi }\end{array}$} & Yeni kayıt & Öğrenci sayısı & Mezun öğrenci & Nicelik göstergeleri (öğretim üyesi \\
\hline & öğrenci sayısı & & say1s1 & başına düşen öğrenci sayısı, v.b.) \\
\hline & Merkezi sinav & Öğretim elemanı & Makale & Nitelik göstergeleri (Öğretim üyesi \\
\hline & & say1s1 & & başına düşen makale sayısı, v.b.) \\
\hline & & Bologna süresi & Alintı & Üstün başarı ödülleri \\
\hline & & $\begin{array}{l}\text { Eğitim-öğretim } \\
\text { faaliyetleri }\end{array}$ & Proje & Yurtdışı eğitim destekleri \\
\hline & & Araştırma \& & Tez & Üniversitelerin sınıflandırılması \\
\hline & & Geliştirme & & (araştırma üniversiteleri, vb.) \\
\hline & & faaliyetleri & & \\
\hline & & Akademik & Kitap/kitap & \\
\hline & & faaliyetler & bölümü & \\
\hline & & Enstitü işleyişi & Bildiri/konferans & \\
\hline \multirow{10}{*}{$\begin{array}{l}\text { Görgül } \\
\text { veri } \\
\text { analizi }\end{array}$} & Kabul şartları & Akademik uyum & Kişisel gelişim & Ders çeşitliliği \\
\hline & Akademisyen & Sosyal uyum & Akademik gelişim & Uygulama \\
\hline & $\begin{array}{l}\text { Kişisel } \\
\text { gelişim }\end{array}$ & Kültürel uyum & Mezuniyet & Ekonomik destek \\
\hline & $\begin{array}{l}\text { Akademik } \\
\text { gelişim }\end{array}$ & $\begin{array}{l}\text { Bürokratik } \\
\text { uyum }\end{array}$ & Yayın & Danışman seçimi \\
\hline & $\begin{array}{l}\text { Görevde } \\
\text { yükselme }\end{array}$ & Ekonomik uyum & Proje & Karar verme yetkisi \\
\hline & Tavsiye & Oryantasyon & Uluslararasılaşma & Lisansüstü destek ofisi \\
\hline & $\begin{array}{l}\text { Kariyer } \\
\text { belirsizliği }\end{array}$ & Akademik birim & Etkileyici CV & Enstitü destek hattı \\
\hline & Farklı alana & Medeni durum & Toplumsal takdir & Dijital belge yönetim sistemi \\
\hline & & Yaş & & \\
\hline & & Program düzeyi & & \\
\hline
\end{tabular}




\section{Tartıșma, Sonuç ve Öneriler}

Çalışmanın sonuçları yaşın, medeni durumun, akademik alanın ve program düzeyinin lisansüstü öğrencilerin örgüt iklimi algılarında anlamlı bir farklılık oluşturduğunu göstermiştir. Ayrıca öğrenciler akademik deneyimler konusunda oldukça olumlu, sosyoekonomik deneyimler konusunda nispeten olumlu, kültürel deneyimler ile yönetimsel deneyimler konularında ise genellikle olumsuz deneyimler ifade etmişlerdir. Çalışmanın doküman analizi lisansüstü eğitimde yap1 ve sürecin sistem öğeleri olan girdi, süreç, çıktı ve geribildirim değişkenleri üzerine kurulu olduğunu göstermiştir.

23-28 yaş grubundaki lisansüstü öğrencilerin 29-34 yaş grubundakilere göre örgüt iklimi algılarının daha yüksek olduğu bulunmuştur. $\mathrm{Bu}$ sonuç alan yazındaki genel eğilimle örtüşmemektedir. Alan yazında yaş ve örgüt iklimi arasındaki ilişkiyi araştıran çalışmalar genellikle aradaki pozitif ilişkiye dikkat çekmektedir. Holloway (2012) yaptığ örgüt iklimi boyutlarından sorumluluk arasında pozitif bir ilişki bulmuştur. Benzer şekilde Türkiye'de gerçekleştirilen Arabacı (2010) ve İşcan ve Karabey'in (2007) çalışmaları da yaş yükseldikçe olumlu örgüt iklimi algısının yükseldiğini bulmuşlardır. Diğer taraftan, Thomas'ın (2008) yaşın arttıkça olumlu örgüt iklimi algısının düştüğünü gösterdiği çalışma bu çalışmanın sonucuyla paralellik taşımaktadır. Özetle, bu çalışma alan yazındaki çeşitliliğe katkı sağlamıştır.

Bekâr öğrencilerin evli öğrencilere göre örgüt iklimi algılarının daha yüksek olduğu bulunmuştur. Bu sonuç, evli olanların aile sorumlulukları ve eğitim sorumlulukları arasındaki rol karmaşası ile ilgili olabilir. Alan yazın hem eğitim ve hem de aile sorumluluklarının yürütülmesinde zorluklar yaşandığına dikkat çekmektedir (Dilci ve Gürol, 2012; Ertem ve Gökalp, 2019a; Özmen ve Aydın-Güç, 2013). Bu çalışmada bekâr ve evliler arasında ortaya çıkan anlamlı fark alan yazınla örtüşmemektedir. Günboyu (2007), Yahşi (2014) ve Yüksekbilgili (2017) yapmış oldukları çalışmada medeni durum ve örgüt iklimi algısı arasında anlamlı bir ilişki tespit edememiştir.

Sağlık bilimlerindeki lisansüstü öğrencilerin örgüt iklimi algıları daha yüksek bulunmuştur. Bu durum Türkiye'deki bağlamla ilgili olabilir. Türkiye'de sağlık ve eğitimle ilgili istihdam diğer alanlara göre daha yüksek görünmektedir. Türkiye'de 2019 y1lı için Sağlik Bakanlığı'na ayrılan kadro sayısı 30 bin civarındadır (Sağlık Bakanlığı, 2019). Ayrıca Covid-19 salgını nedeniyle 2020 yılı Nisan ayı içinde 32 bin kişilik bir istihdam daha oluşturulmuştur (Sağlık Bakanlığı, 2020). Çalışmanın bu sonucu bölüm ya da birimleri arası farklılaşmalar tespit eden çalışmalarla benzer haldedir. Örneğin, İşçan ve Karabey (2007) örgüt iklimi ile yeniliğe destek arasındaki ilişkiyi araştırdığı çalışmasında örgüt iklimi algısının birimlere göre farklılaştığını bulmuştur. Ayrıca bu çalışma gibi yazarların araştırması da tüm değişkenler içinde en büyük etkiyi birim farklılaşmasının yaptığını ortaya koymuştur.

Yüksek lisans öğrencilerinin Doktora öğrencilerine göre daha olumlu bir iklim algısına sahip olduğu ortaya çıkmıştır. Bu durum doktora öğrencilerinin lisansüstü eğitimde daha fazla zaman geçirdiklerinden yüksek lisans öğrencilerine göre olumsuz deneyimlerinin daha fazla olmasıyla ilgili olabilir. Özellikle uluslararası alan yazın lisansüstü eğitim öğrencilerinin ilk ve son yıllarındaki deneyim farklılaşmalarına odaklanmaktadır (Golde, 1998; Jensen, Doumas ve Midgett, 2016; Lawson, 1981). Yüksek lisans ile doktora eğitimindeki farklılaşmalar ulusal alan yazındaki araştırmalara konu olmuştur. Ertem ve Gökalp (2016) yaptıkları çalışmada yüksek lisans öğrencilerinin doktora öğrencilerine göre okulda daha az tutunduklarını bulmuştur.

Lisansüstü eğitim alan öğrencilerinin deneyimlerinin akademik, sosyoekonomik, kültürel ve yönetimsel boyutlarda toplanabildiği ortaya çıkmıştır. Ders içerikleri ve kuram-uygulama ilişkisi akademik deneyimler, sosyal ilişkiler ve ekonomik destek sosyoekonomik deneyimler, ilk yıl uyumu ve danışmanla iletişim kültürel deneyimler ve bürokratik süreçler ve bölüm dinamikleri ise yönetimsel deneyimler olarak dikkat çekmiş olup tüm bu deneyimler alan yazın ile uyumlu haldedir (Bülbül, 2003; Chemers, Hu ve Garcia, 2001; Gömleksiz ve Yıldırım, 2016; Kahraman ve Tok, 2016; Sözer ve diğerleri, 2002; Stieha, 2010). Bu çalışma gibi alan yazındaki diğer çalışmaların da lisansüstü deneyimleri sınıflamaya çalıştığı ve memnun olunmayan deneyimler için öneriler sunduğu görülmektedir. 
Lisansüstü eğitimdeki yapı ve sürecin girdi, süreç, çıktı ve geribildirim öğeleri ile ilişkilendirilebilmesi alan yazında okulu açık sistem olarak gören çalışmalarla benzer haldedir. Yalçınkaya (2002) açık sistem kuramını okula uygulamış, insan, bilgi, teknoloji ve finansmanı girdi, insan, yapı, yönetim, eğitim-öğretim süreçleri, fiziki yapı, teknoloji ve araştırmageliştirmeyi süreç, eğitilmiş öğrenci, ürünler, hizmet ve parayı çıktı ve memnuniyet ve sonuçları ise geribildirim olarak ifade etmiştir. Diğer taraftan lisansüstü eğitimdeki yap1 ve süreçteki değişkenler yükseköğretimde reformu odağa alan politika çalışmalarıyla uyumlu haldedir. Araştırma üniversitelerinin araştırma ve öğretim sorumlulukları (Bakioğlu ve Tatık, 2020), araştırma üniversitelerinde yapılanma (Erdoğmuş, 2018) ve akademisyen yetiştirme politikaları (Gümüş ve Gökbel, 2012) bu çalışmadaki bulgulara paraleldir.

Araştırmanın sonuçları araştırma, kuram ve uygulama boyutlarında önemli çıkarımlara dikkat çekmektedir. Öncelikle yürütülen karma model çalışma ile lisansüstü eğitimdeki yapı ve süreç değişkenlerinin ortaya çıkarılması Türkiye alan yazınında önemli bir katkı sunmuştur. Lisansüstü eğitim sorunlarına odaklanan eğilim yerine lisansüstü eğitimle ilgili modellemeler yapan eğilimler lisansüstü eğitim alan yazınını hem nicelik hem de nitelik olarak geliştirecektir. Dolayısıyla bu durum araştırmacıların lisansüstü eğitime bütüncül ve çok boyutlu yaklaşmalarına katkı sağlayacaktır. Kuramsal açıdan yaklaşıldığında ise sistem kuramlarının eğitim-öğretim kurumlarında işlevinin devam ettiği ama bir yandan da kültürel çeşitlilik ve sosyal adalet gibi değerlerin bu sistemlerle bütünleştirilmesi gerektiği fikri daha çok anlam kazanacaktır. Diğer taraftan, yükseköğretim alanındaki politika yapıcılar, yükseköğretim kurumları yöneticileri ve uygulayıcıları lisansüstü eğitimde yapı ve sürecin sağlıklı işleyebilmesi için belirli planlamalar yapabilecektir. Olumlu örgüt iklimi oluşturma etkinliklerinden daha fazla doktoralı yetiştirme stratejilere kadar birçok reform uygulaması gündeme gelebilecektir.

Çalışmanın karma model deseniyle yürütülmüş olması çalışmanın en güçlü yönlerinden olmakla birlikte bazı noktalarda çalışmanın sınırlıklarından söz edilebilir. Öncelikle çalışmanın sonuçları sadece altı araştırma üniversitesi ile sınırlı olduğundan araştırmacılara araştırma üniversitelerinin tamamına ilişkin daha büyük bir çalışma yürütmeleri önerilmektedir. Ayrıca, bölgesel kalkınma odaklı üniversiteler ile herhangi bir sınıflandırmaya girmeyen diğer üniversitelerde de benzer araştırmalar yapılarak lisansüstü eğitimdeki yapı ve sürecin farklılaşıp farklılaşmadığı çalışılabilir. Bu çalışma sadece lisansüstü öğrencilerin deneyimlerine dayandığ için daha farklı bakış açılarını da dâhil etmek üzere araştırmacıların öğretim üyelerinin katılımcı olduğu benzer çalışmalar yürütmesi önerilmektedir. Diğer taraftan, bu çalışmanın sonuçları ve çıkarımları göz önüne alınarak uygulayıcılar için öneriler geliştirilmiştir. Lisansüstü eğitimle ilgili planlamalar yapılırken öğrencilerin demografik bilgilerinin dikkate alınması, örgüt iklimini geliştirici etkinlikler düzenlenmesi, lisansüstü eğitimde nicelikle birlikte niteliği de dikkat edilmesi, lisansüstü eğitim alanında reformlar yapılırken lisansüstü eğitimin girdisinden çıktısına kadar tüm yapı ve sürecin bütüncül bakış açısıyla değerlendirilmesi ve öğrencilerin hayatlarına dokunan iş ve burs gibi destek programlarının yürütülmesi önerilmektedir.

\section{Etik Kurul Onay Bilgileri}

Bu çalışmada "Yükseköğretim Kurumları Bilimsel Araştırma ve Yayın Etiği Yönergesi" kapsamında uyulması belirtilen tüm kurallara uyulmuştur. Yönergenin ikinci bölümü olan "Bilimsel Araştırma ve Yayın Etiğine Aykırı Eylemler" başlığı altında belirtilen eylemlerden hiçbiri gerçekleştirilmemiştir. Çalışma, Zonguldak Bülent Ecevit Üniversitesi İnsan Araştırmaları Etik Kurulu'nun 27.06.2019 tarihli ve 597 protokol nolu etik kurul onayına sahiptir.

\section{Kaynaklar}

Akbulut, H. İ, Şahin, Ç. ve Çepni, S. (2013). Doktora tez sürecinde karşılaşılan problemlerin belirlenmesi: Eğitim Fakültesi örneği. Dicle Üniversitesi Ziya Gökalp Ĕ̈itim Fakültesi Dergisi, 20(2013), 50-69.

Alabaş, R., Kamer, S. T. ve Polat, Ü. (2012). Öğretmenlerin kariyer gelişimlerinde lisansüstü eğitim: tercih sebepleri ve süreçte karşilaştiklari sorunlar. E-International Journal of Educational Research, 3(4), 89-107 
Arabac1, I. B. (2010). Academic and administration personnel's perceptions of organizational climate (Sample of Educational Faculty of Frat University). Procedia-Social and Behavioral Sciences, 2(2), 4445-4450.

Araque, F., Roldán, C. ve Salguero, A. (2009). Factors influencing university dropout rates. Computers \& Education, 53(3), 563-574.

Aslan, G. (2007). Ankara Üniversitesi Eğitim Bilimleri Enstitüsüne kayıtlı doktora öğrencilerinin lisansüstü öğretime ilişkin sorunları. Milli Eğitim Dergisi, 174, 250-269.

Bakioğlu, A. ve Tatık, R. Ş. (2020). Öğretim ve araştırma sorumluluklarının dağılımının araştırma üniversiteleri bağlamında incelenmesi. Abant İzzet Baysal Üniversitesi Ĕgitim Fakültesi Dergisi, 20(1), 548-569.

Bergquist, W. H. ve Pawlak, K. (2008). Engaging the six cultures of the academy: Revised and expanded edition of the four cultures of the academy ( 2 nd ed.) John Wiley \& Sons.

Bess, J. L. ve Dee, J. R. (2008). Understanding college and university organization: Dynamics of the system (Vol. 2). Stylus Publishing, LLC.

Bozan, M. (2012). Lisansüstü eğitimde nitelik arayışlar. Sosyal ve Beşeri Bilimler Dergisi, 4(2), $177-187$.

Bülbül, T. (2003). Ankara Üniversitesi Eğitim Bilimleri Fakültesinde görev yapan öğretim üyelerinin lisansüstü öğretime öğrenci seçme sürecine ilişkin görüşleri. Ankara Üniversitesi Ĕgitim Bilimleri Fakültesi Dergisi, 36(1), 167-174.

Celep, C. ve Konakl1, T. (2013). Mobbing experiences of instructors: causes, results, and solution suggestions. Educational Sciences: Theory \& Practice,13(1), 193-199.

Chemers, M. M., Hu, L. T. ve Garcia, B. F. (2001). Academic self-efficacy and first year college student performance and adjustment. Journal of Educational psychology, 93(1), 5564.

Cohen, J. (1992). A power primer. Psychological Bulletin, 112(1), 155-159.

Creswell, J. W. (2012). Educational research: planning, conducting, and evaluating quantitative and qualitative research. New York: NY. Pearson.

Çelik, Z. ve Gür, B. S. (2014). Yükseköğretim sistemlerinin yönetimi ve üniversite özerkliği: küresel eğilimler ve Türkiye örneği. Journal of Higher Education \& Science/Yüksekögretim ve Bilim Dergisi, 4(1), 18-27.

Dilci, T. ve Gürol, M. (2012). Öğretim üyeleri bakış açısıyla lisansüstü eğitiminin yaşam alanına yansımaları: eğitim bilimleri örneklemi. Kastamonu Eğitim Dergisi, 20(3), 1073-1090.

Doğan, D. (2013). Yeni kurulan üniversitelerin sorunlari ve çözüm öneriler. Journal of Higher Education \& Science/Yüksekögretim ve Bilim Dergisi, 3(2), 108-116.

El-Khawas, E. (2007). Accountability and quality assurance: New issues for academic inquiry. International handbook of higher education içinde (ss. 23-37). Springer, Dordrecht.

Erdoğmuş, N. (2018). Araştırma üniversitesi yapılanmast: imkânlar ve zorluklar. İlke politika notu.

Ersöz, F., Kabak, M. ve Yilmaz, Z. (2011). Lisanüstü ögrenimde ders seçimine yönelik bir model önerisi. Afyon Kocatepe Üniversitesi Iktisadi ve Idari Bilimler Fakültesi Dergisi, 13(2), 227-249.

Ertem, H. Y. ve Gökalp, G. (2016). Sayıların dili: Lisansüstü eğitimde okul terki. K. Beycioğlu, N. Özer, D, Koşar ve İ. Şahin (Yay. haz.). Eğitim yönetimi araştırmaları içinde (ss. 239250). Ankara: PegemA.

Ertem, H. Y. (2018). The Role of Personal and Organizational Factors on Student Attrition from Gradute Education. Do or Die? (Doktora tezi). ODTÜ, Ankara.

Ertem, H. Y. ve Gökalp, G. (2019a). Role of personal and organizational factors on student attrition from graduate education: A mixed-model research. Journal of College Student Retention: Research, Theory \& Practice. http://dx.doi.org/10.1177/1521025119881391

Ertem, H. Y. ve Gökalp, G. (2019b). Lisansüstü Eğitim'de Örgüt İklimi Ölçeği’nin geliştirilmesi. İnönü Üniversitesi Eğitim Fakültesi Dergisi, 20(3), 784-797.

Esterman, T., Nokkala, T. ve Steinel, M. (2011). University Autonomy in Europe II. Erişim adresi: https://eua.eu/component/publications/publications/79-report/401-universityautonomy-in-europe-ii-the-scorecard.html. 
Fazlığullari, O. ve Kurul, N. (2012). Türkiyedeki eğitim bilimleri doktora tezlerinin karakterisitkleri. Mehmet Akif Ersoy Üniversitesi Eğitim Fakültesi Dergisi, 1(24), 43-75.

Ferreira, M. (2003). Gender issues related to graduate student attrition in two science departments. International Journal of Science Education, 25(8), 969-989.

Golde, C. M. (1998). Beginning graduate school: Explaining first-year doctoral attrition. New Directions for Higher Education, 1998(101), 55-64

Gömleksiz, M. N. ve Yıldırım, F. (2013). Lisansüstü eğitim alan öğrencilerin lisansüstü eğitime ilişkin görüşleri. VI. Ulusal Lisansüstü Eğitim Sempozyumu, 68-74.

Gölpek, F. (2011). Yükseköğretimin getirileri ve etkinlik sorunu. Atatürk Üniversitesi İktisadi ve Ídari Bilimler Dergisi, 25(3-4), 77-95

Gravetter, F. J. ve Wallnau, L. B. (2013). Statistics for the behavioral sciences, London: Thomson Wadsworth.

Gümüş, S. ve Gökbel, V. (2012). 2023 için akademisyen yetiştirme çabaları: MEB ve YÖK yurtdışı lisansüstü bursları (No. 56). Ankara: Siyaset, Ekonomi ve Toplum Araştırmaları Vakfi.

Güven, İ. ve Tunç, B. (2007). Lisansüstü öğretim öğrencilerinin akademik sorunları (Ankara Üniversitesi Eğitim Bilimleri Enstitüsü örneği). Milli Eğitim Dergisi, 173, 157-172.

Hauptman, A. M. (2007). Higher education finance: trends and issues. International Handbook of Higher Education içinde (ss. 83-106). Springer, Dordrecht.

Holloway, J. B. (2012). Leadership behavior and organizational climate: An empirical study in a non-profit organization. Emerging leadership journeys, 5(1), 9-35.

Hoy, W. K. ve Miskel, C. G. (1991). Educational administration: Theory, research, and practice, 4 th edition. New York: McGraw-Hill.

Ishitani, T. T. (2006). Studying attrition and degree completion behavior among first-generation college students in the United States. Journal of Higher Education, 861-885.

İşcan, Ö. F. ve Karabey, C. N. (2007). Örgüt iklimi ile yeniliğe destek algısı arasındaki ilişki. Gaziantep Üniversitesi Sosyal Bilimler Dergisi, 6(2), 180-193.

Jensen, J. D., Doumas, D. M. ve Midgett, A. (2016). Enhancing program satisfaction and retention among first-year master of arts in counseling students: A qualitative study. ACA Knowledge Center, 33.

Kahraman, Ü. ve Tok, T. N. (2015). Eğitim yönetimi denetimi planlaması ve ekonomisi lisansüstü öğrencilerinin aldıkları eğitim hakkındaki görüşleri. Uşak Üniversitesi Sosyal Bilimler Dergisi, 9(1), 147-164.

Karakul-Kayahan, A. ve Karakütük, K. (2014). Views of academics on student selection criteria for graduate education. Journal of Faculty of Educational Sciences, 47(2), 179-200.

Karakütük, K., Aydın, A., Abalı, G. ve Yıldırım, S. (2008). Lisansüstü öğretimin sorunları konusunda Ankara'daki üniversitelerin lisansüstü enstitü yöneticilerinin görüşleri. Eğitim ve Bilim, 33(147), 42-53.

Karaman, S. ve Bakırc1, F. (2010). Türkiye'de lisansüstü eğitim: sorunlar ve çözüm önerileri. Sosyal Bilimler Araştırmaları Dergisi, 2, 94-114.

Lawson, J. M. (1981). The relationship between graduate education and the development of reflective judgment: A function of age or educational experience.

Long, M., Ferrier, F. ve Heagney, M. (2006). Stay, play or give it away? students continuing, changing or leaving university study in first year. Centre for the Economics of Education and Training, Monash University.

Lott, J. L., Gardner, S. ve Powers, D. A. (2009). Doctoral student attrition in the STEM fields: An exploratory event history analysis. Journal of College Student Retention: Research, Theory \& Practice, 11(2), 247-266

Metzner, B. S. ve Bean, J. P. (1987). The estimation of a conceptual model of nontraditional undergraduate student attrition. Research in Higher Education, 27(1), 15-38.

Organization for Economic Cooperation and Development. (2015). Education at a glance-2015 highlights. 
Organization for Economic Cooperation and Development. (2017). Education at a glance-2017 highlights.

Ozan, C. ve Köse, E. (2014). Eğitim programları ve öğretim alanındaki araştırma eğilimleri. Sakarya University Journal of Education, 4(1), 116-136.

Ölçer, N. ve Koçer, S. (2015). Örgütsel iletişim: Kocaeli Üniversitesi akademik personeli üzerine bir inceleme. Global Media Journal TR Edition, 6(11), 339-383.

Özer, Y. E. (2011). Girişimci üniversite modeli ve Türkiye. Uludă̆ Üniversitesi İktisadi ve İdari Bilimler Fakültesi Dergisi, 30(2), 85-100.

Özmen, Z. M. ve Aydın-Güç, F. (2013). Doktora eğitimi ile ilgili yaşanan zorluklar ve baş etme stratejileri: Durum çalışması. Yükseköğretim ve Bilim Dergisi, 3(3), 214-219.

Öztemel, E. (2013). Yükseköğretim kurumlarında araştırma ve inovasyon kültürünün oluşturulması. Yüksekögrretim Dergisi, 3(1), 22-29.

Sağlık Bakanlığı. (2019). Yönetim Hizmetleri Genel Müdürlüğü. Erişim adresi: https://yhgm.saglik.gov.tr/TR,56932/kpss-20194-saglik-bakanligi-sozlesmeli-saglikpersoneli-alimi-hakkinda-duyuru.html

Sağlık Bakanlığı. (2020). Yönetim Hizmetleri Genel Müdürlüğü. Erişim adresi: https://yhgm.saglik.gov.tr/TR,63943/2020-yili-ilk-defa-ve-yeniden-atama-kurasi.html

Sözer, A. N., Tütüncü, Ö., Doğan, Ö., Gencel, U., Gül, H. ve Devebakan, N. (2002). Dokuz Eylül Üniversitesi Sosyal Bilimler Enstitüsü'nde lisansüstü eğitim kalitesinin arttırılmasına yönelik bir alan araştırması. Sosyal Bilimler Enstitüsü Dergisi, 4(2), 41-65.

Stieha, V. (2010). Expectations and experiences: The voice of a first-generation first-year college student and the question of student persistence. International Journal of Qualitative Studies in Education, 23(2), 237-249.

Şen, Z. (2012). Türkiye'de yükseköğretim sistemi eleştirileri ve öneriler. Yüksekögretim Dergisi, 2(1), 1-9.

Teddlie, C. ve Tashakkori, A. (2003). Major issues and controveries in the use of mixed methods in the social and behvioral sciences. Handbook of Mixed Methods in Social \& Behavioral Research, 3-50.

Thomas, J. C. (2008). Administrative, faculty, and staff perceptions of organizational climate and commitment in Christian higher education. Christian Higher Education, 7(3), 226-252.

Yahşi, Ü. Y (2014). Gençlik ve Spor Bakanlığı personelinin örgüt iklimi algıları ile örgütsel yaratıcılık düzeyleri. Doktora Tezi, Ankara Üniversitesi, Ankara.

Yalçınkaya, M. (2002). Açık sistem teorisi ve okula uygulanması. Gazi Üniversitesi Gazi Eğitim Fakültesi Dergisi, 22(2), 103-116.

Yıldırım, A. ve Şimşek, H. (1993). Nitel araştırma yöntemleri. Ankara: Seçkin Yayınevi

Yüceler, A. (2009). Örgütsel bağlllık ve örgüt iklimi ilişkisi: Teorik ve uygulamalı bir çalışma. Selçuk Üniversitesi Sosyal Bilimler Enstitüsü Dergisi, 22, 445-458.

Yüksekbilgili, Ö. (2017). Özel sağlık işletmeleri çalışanlarının örgüt iklimi algılarının demografik özelliklerine göre incelenmesi. İktisadi İdari ve Siyasal Araştırmalar Dergisi (IKTISAD), 2(2), 45-60.

Yükseköğretim Kurulu Başkanlığı. (2018). YÖK İstatistik. Erişim adresi: https://istatistik.yok.gov.tr/.

\section{Extended Abstract}

\section{Introduction}

The current study aimed to reveal out structure and process in graduate education by determining factors related to organizational climate perceptions of graduate students and examining their graduate experiences. Graduate education is a kind of higher education level offering academic, economic, political, and sociological contributions. Graduate education contributes to higher education academically by feeding teaching mission of undergraduate education through curriculum studies. In terms of economic dimension, graduate education provides contribution to research and development activities by training stronger researchers. Qualified academician 
training issue is also political side of graduate education such that politicians may implement different policies through graduate education to assign academicians. And finally, graduate education is a kind of sociological phenomenon such that individuals from different fields register to graduate education in order to develop themselves in their fields.

Organizational climate can be evaluated as an indicators representing atmosphere in the organization. Hoy and Miskel (1991) defined organizational climate as shared perceptions of people about their working environment. Scholars in different fields examine organizational climate. To name a few, studies investigating climate in supermarkets (Batlis, 1980), medical institutions (Welsch \& LaVan, 1981), and hotels (Davidson, 2003) showed that organizational climate is significant for all institutions. Apart from service institutions, educational institutions have also a kind of climate. Especially, higher education institutions have a complex process and structure. To illustrate, upper secondary education, undergraduate education, and graduate education as levels of higher education have different characteristics such that they may be explained with organizational climate.

In Turkey, there were most of organizational climate studies related to undergraduate level of higher education (Yüceler, 2009). The researcher of the current study came up with a study related to organizational climate in graduate education level (Ertem \& Gökalp, 2019b), which is a scale development study.

\section{Method}

The design of the current study was mixed-method. In other words, quantitative methods were mixed with qualitative methods in all sections from problem statement to the discussion of findings. Quantitative method was based on causal-comparative study while qualitative method was based on phenomenological study. Quantitative part checked variables making significant changes on organizational climate while qualitative part examined experiences of graduate students. For the quantitative part, dependent variable was organizational climate whereas independent variables were program level, academic field, marital status, gender, semester, and age. For quantitative part, initial themes were related to academic, socioeconomic, cultural, and administrative experiences. The population of the study was graduate students in research universities. Sample consisted of 442 graduate students from six research universities. There were three types of data collection tool. The first one was a questionnaire including demographic and descriptive questions with organizational climate scale. The second one was semi-structured interview questions in order to learn experiences of participants. The last one is web site of CoHE to check variables related to graduate education. Quantitative data were analyzed via one-way and two-way ANOVA while qualitative data were performed with content analysis. Document data were also analyzed with content analysis to describe input, process, output, and feedback indicators of graduate education.

\section{Results and Discussion}

The study showed that academic field, age, marital status, and program level made significant differences on organizational climate whereas effects of gender and semester were found nonsignificant. Among significant variables, academic field had the largest effect size. Moreover, academic and socioeconomic experiences appeared more positive than cultural and administrative experiences. Further, document analysis revealed that process and structure in graduate education fitted on the variables of input, process, output, and feedback.

The current study has implications in terms of research, theory, and practice. By considering, holistic view on graduate education is an attempt to fill a gap in the literature. In terms of theory, the study gives an opportunity to synthesize approach of system theories with popular values such as cultural diversity and social justice. Finally, policy-makers and practitioners in higher education may consider strategies to improve process and structure in graduate education.

The researcher of the current study recommends important issues both researchers and practitioners. Researchers could investigate organizational climate together with other variables 
in larger samples. Further, comparisons between research universities and universities focused on regional improvement may be done by researchers. Researchers could include other stakeholders like faculty members to examine process and structure in graduate education. On the other hand, results and implications of the current study bring together recommendations to practitioners and policy-makers. To name a few, consideration of demographic identities of students, implementation of activities to improve organizational climate, improving graduate education as both quantity and quality, evaluating graduate education with holistic perspectives, and supporting students in many dimensions are offered. 